\title{
1. Urban paradigm shifts in emerging economies
}

\author{
Jan Fransen, Meine Pieter van Dijk and \\ Jurian Edelenbos
}

\section{INTRODUCTION}

The main purpose of this book is to identify and understand urban paradigms in emerging economies. Kuhn (2012: viii) defines paradigms as "universally recognized scientific achievements that for a time provide model problems and solutions to a community of practitioners". In this chapter we focus on models that indicate how to intervene in cities and identify paradigm shifts for which subsequent chapters of the book offer theoretical depth and/or case studies from different countries and domains. The ultimate objective of this book is to learn about the identified paradigms (how) as applied by different approaches (what) in different cities in emerging economies (where).

The reason to focus on emerging economies is that they face high rates of urbanization. Urban models predict that by 2025 nine of the twelve biggest cities will be in emerging economies. Asia alone is likely to have seven of the twelve biggest cities. In Africa, both Lagos and Kinshasa are each likely to have grown to more than 15 million residents (Roberts, 2011). Rapid urbanization has a major effect on the environment, poverty and the availability of resources worldwide. It demands an immense urban management effort, which far outstrips the current urban management capacity in emerging economies. Equally important, it demands a reflection on how we manage cities.

Urban paradigms have shifted over the past century. In broad brush terms, the way to intervene in cities altered from urban planning by central governments for most of the twentieth century, to decentralized urban management with privatized service delivery in the 1980s and 1990s, to urban governance in the new millennium (Table 1.1). The shifts exemplify a realization that effective and efficient service delivery on its own does not address wicked problems in increasingly complex urban systems. However, while new problems have attracted the attention of policy makers and researchers, old problems have not disappeared. 
Table $1.1 \quad$ Urban paradigm shifts

\begin{tabular}{llll}
\hline Time period & Problem addressed & Urban paradigm & $\begin{array}{l}\text { Public administration } \\
\text { paradigm }\end{array}$ \\
\hline $1900-1980$ & $\begin{array}{l}\text { Shortage in services and } \\
\text { infrastructure }\end{array}$ & $\begin{array}{l}\text { Central planning as } \\
\text { a reaction to market } \\
\text { failure }\end{array}$ & $\begin{array}{l}\text { Traditional Public } \\
\text { Administration }\end{array}$ \\
& Inefficient service & $\begin{array}{l}\text { Urban management as } \\
\text { a reaction to government } \\
\text { delivery }\end{array}$ & New Public Management \\
& & $\begin{array}{l}\text { failure } \\
\text { Wicked problems }\end{array}$ & Urban governance as \\
& & a reaction to both market & \\
& & and government failure & \\
\hline
\end{tabular}

Source: Authors.

After describing these paradigm shifts, the chapter argues that any urban problem demands an eclectic mix of urban planning, management and governance. The reframing of problems results in new concepts such as smart, resilient, creative, sustainable cities. While these concepts partially pour the same wine in new bottles, they also offer inspiring entry points for urban development.

We end the chapter by anticipating the next paradigm shift, whereby the role of (local) government increases once again. Market-led development has been criticized due to its inability to deal with wicked problems. At the same time, governments have played a major role during the COVID-19 pandemic. With climate change and urban resilience high on the political agenda, the role of (local) governments is likely to increase. But urban managers work in highly differentiated political settings, local contexts and local capacities. As a novel approach, we introduce a 'governance possibility frontier' (adapted from Djankov et al., 2003), which describes minimum levels of planning, management and governance required under different political settings. We propose boundary spanning as an eclectic way to bring actors and processes together. The urban examples presented in the book subsequently offer rich examples of a reflexive stance on urban planning, management and governance.

\section{REFRAMING URBAN PROBLEMS}

Industrializing cities in the late nineteenth century resembled Charles Dickens' Coke Town, the fictional town he depicted in his 1854 novel Hard Times. In this industrial mill town every building looked the same and was covered in soot, the air quality was appalling, the society was unequal and segregated, infrastructure, housing and services were inadequate, and working hours were 
long and the work boring. Urban markets failed to deliver housing, drainage, education, health facilities and other basic services. This led to negative externalities such as pollution, segregation and depression. For most of the twentieth century, the problem of cities was framed in terms of poor infrastructure and service delivery caused by urbanization and industrialization (Bettencourt, 2013). To frame it more broadly: the identified problem was market failure. To the extent that resources allowed, a welfare state or socialist regime delivered centralized public services and infrastructure, funded from taxation and official development aid, in order to overcome market failure (Hemerijck, 2013). Governments worldwide set minimum wages and, when viable, offered unemployment benefits. In socialist countries, salaries were standardized. Keynes (1936) argued that these measures not only reduced poverty, but also stabilized demand thereby dampening recessions and smoothing economic progress. At the same time, developing countries supported industries and adopted import substitution industrialization (ISI) strategies in order to protect their investments. Labour-based industries relocated to developing countries, developing economies grew relatively quickly and despite neo-Marxist criticism there was an overall belief that developing countries would catch up over time (Jaret, 1983; Rostov, 1960).

To fund the welfare state, however, developing countries borrowed huge sums of money from international creditors. This proved to be a risky public investment, leading to a massive debt crisis in Latin American countries. It was quickly realized that not only Latin American governments had overspent. With countries being unable to fund basic services and infrastructure and repay loans, the development problem was reframed as government failure: nepotism, red tape, centralized decision making and a poor understanding of economic risks resulted in inefficient service delivery and failed industrialization investments (de Soto, 1989; Stiglitz, 1998). Privatization became the new saviour to enable developing countries to reduce costs, repay loans and deliver urban services more efficiently. Structural adjustment programmes brought down government expenditures, by privatizing services such as education almost overnight (Sahn et al., 1999; Stiglitz, 1991).

Over time, urban issues became more complex, facing wicked problems such as climate change, economic crises, traffic congestion and growing inequality (Head and Alford, 2015). A wicked problem is a problem that is difficult or impossible to solve because of incomplete, contradictory, and changing requirements (Rittel and Webber, 1973). 'Wicked' denotes resistance to resolution and implies that it has no determinable stopping point, because the interdependency between issues means that the effort to solve one aspect of a wicked problem may reveal or create other problems (Tonkinwise, 2015).

These kinds of wicked problems are highly visible in cities in emerging economies. For instance, the 30 most polluted cities are in emerging econo- 
mies (WHO, 2018). For a wicked problem such as climate change, there is no clearly defined cause or solution. Different actors have different perspectives of the problems, priorities and solutions (Kickert et al., 1997). Wicked urban problems arise in complex systems such as cities (Bettencourt, 2013). Complex systems are self-organised, in the sense that markets and social networks create "order without design", as Bertaud's (2018) latest book is aptly called. Successful behaviour is reinforced by feedback mechanisms. Cities create positive feedback mechanisms in processes of matching, sharing and learning (Duranton and Puga, 2004). Firms in related industries are rewarded by productivity gains, as they benefit from matching in labour markets, sharing of infrastructure and learning in knowledge networks. This attracts more related industries (Neffke et al., 2018). However, the high density in cities also leads to negative externalities (the wicked problems), such as pollution, heat waves, traffic congestion, crime, stress, social exclusion and inequality.

\section{EVOLVING PARADIGMS}

The development of new urban paradigms reflects the reframing of urban problems and a related debate on the role of governments (and other stakeholders) in the urban realm. Public administration and public policy scholars have reacted to the reframing of problems by suggesting a shift from Traditional Public Administration to New Public Management, and a further shift to a, yet incoherently described, third paradigm, often called New Public Governance (Osborne, 2006).

\section{Traditional Public Administration}

Traditional Public Administration arose in the early twentieth century as a response to the challenges of, amongst others, industrialization, urbanization, and major market failure (Stoker, 2006). In an idealized form, politics and administration were separated, and neutrality as well as equality in government operations were highly valued, based on the rule of law. Public servants pursued politically provided objectives. There are basically two dominant logics within this paradigm: standardization and internal orientation (Nederhand et al., 2019). The primary logic is that of standardization (Weber, 1978). From this logic, the function of policy officials should be standardized and executed along the lines of predictable processes and rules. The explicit standardization of functions makes interaction with the bureaucratic organization perfectly predictable. This predictability is also safeguarded by the presence of impersonal and stable rules (Wilson, 1989). The second major characteristic is the internal orientation of policy officials. The emphasis on both administrative procedures and serving the political officeholders makes 
policy officials internally oriented. Hence, political decisions guide the actions of policy officials. This internal orientation on policy programmes and rules also enables policy officials to treat each citizen alike.

Urban development was perceived as a process of centralized planning. Planners produced master plans, delivered infrastructure and services and subsequently checked building permits and minimum building standards. Local authorities comprised departments that were devolved from national ministries. Highly detailed urban planning models, such as the garden city or Le Corbusier's Ville Radieuse, were implemented on a massive scale irrespective of the local context (Bertaud, 2018; Bettencourt, 2013). Centralized planning was inspired by engineering practices and control theories. While these control tendencies are criticized these days, centralized urban planning was instrumental in changing Dickensian 'Coke Towns' into serviced urban centres, whereby costs were reduced by mass production and ever-reducing transport costs (Bettencourt, 2013). The World Bank (2000) argues that even now successful urban development also requires strategic urban or regional planning in order to attract investments and physically locate employment, houses, amenities and transport infrastructure.

\section{Urban Management}

New Public Management (NPM) arose in the 1980s out of concern for government failure, and a belief in the efficiency and effectiveness of market mechanisms and economic rationality (Hood, 1991). It implied a break from centralized government towards decentralization, privatization and publicprivate partnerships (PPPs). Politically provided goals were now implemented by public managers using markets, managing inputs and outputs such that they ensured economic welfare and responsiveness to 'customers' (i.e. citizens) (Bryson et al., 2014). The managerial logic is grounded in a neoliberal approach. While it is difficult to provide a definitive image of NPM (Pollitt et al., 2007), most scholars agree on the main features. These include the focus on improving the efficiency and effectiveness of public service delivery through management of processes and systems. The use of business instruments (strategic and performance management techniques, performance indicators) is crucial to the conceptualization of NPM (Hood, 1991). After politicians have defined and set the main policy goals for the bureaucratic organization, public managers are expected to manage the delivery of these policy goals within budget (Du Gay, 2008). Consequently, problems are translated into managerial targets. Financial resources are subsequently disaggregated into specific organizational units that should realize these targets and results. Results measured in terms of outputs and outcomes are important for purposes of accountability and efficiency (Haque, 2007). There are basically two logics in this paradigm 
(Nederhand et al., 2019): functional specialization and result-orientation. Policy ambitions are broken down into a large set of measurable smaller tasks that are allocated among functionally specialized departments and responsible policy officials. Achieving managerial results within budget is key for policy officials as that is what they are held accountable for. This potentially leaves little room and time for policy officials to deal with extra tasks that come up during interactions with citizens, and therefore fall outside their performance indicators (Bartels, 2016).

In time, the criticism of NPM led to the broader perspective of urban management. Van Dijk (2006: 7) defines urban management as 'the effort to co-ordinate and integrate public as well as private actions to tackle the major problems the inhabitants of cities are facing and to make a more competitive, equitable and sustainable city'. Urban management is multi-sector and multi-actor (Cheema, 1993) and should be concerned with the economic basis of the city, the environment, and participation of and equality among its citizens (Devas and Radkodi, 1993). The role of urban managers is to coordinate horizontally and vertically across government layers, outsource service delivery to private firms and public-private partnerships, improve urban competitiveness and foreign direct investments, enable community participation to ensure targeted service delivery, and manage municipal finance. At the same time, urban planning remains a core responsibility. Consensus building with inhabitants, entrepreneurs, organizations of inhabitants or entrepreneurs, environmental activists and project developers (or organizations of these actors) enables the development and execution of urban policies and strategies (Van Dijk, 2006).

\section{Urban Governance}

Since the 2000s, it is claimed that, although the challenges underlying the rise of the first two paradigms have not disappeared, new challenges have emerged. Our society is more complex than ever, facing wicked problems such as climate change, economic failure, urbanization, and growing inequality (Head and Alford, 2015). The public sector responses to these challenges within society do not constitute a coherent (third) paradigm yet, but scholarly work has been published on, for example, New Public Service (Denhardt and Denhardt, 2000), New Public Governance (Osborne, 2006), Public Value Management (Stoker, 2006) and Public Value Governance (Bryson et al., 2015). At the heart of the emerging paradigm lies the idea that policy goals and policy implementation are discussed and pursued not in a hierarchical way (Traditional Public Administration) or through markets (New Public Management), but by collaborative networks of public and private actors and citizens. Healey (1995: 18) states that urban governance departs from the 
control perspective, because it is realized that urban managers and planners cannot know all the information held by the immense number of heterogeneous agents in cities and cannot predict the dynamics of complex systems. In urban governance, many developmental choices are therefore left open and/ or are discussed in networks (Bettencourt, 2013). Moreover, the legitimacy of politically provided objectives is increasingly questioned.

In this third paradigm, which closely resembles the concepts and ideas of network governance (Koppenjan and Klijn, 2004), the primary logics are those of interdependency, external/context orientation and collaboration (Edelenbos and Teisman, 2011; Torfing et al., 2012). Every government agency depends on several stakeholders with specific resources that cannot be easily substituted (knowledge, legitimacy, formal consent, money, etc.). Network theories perceive the public domain as a complex governance network with layers and departments that are interconnected (Kooiman, 2003; Rhodes, 1996).

Network governance approaches result from the shift of emphasis away from structural devolution, disaggregation and single-purpose organizations and towards a so-called 'whole-of-government' or 'joined-up government' approach (Pollitt, 2003; Christensen and Lægreid, 2007). These initiatives are focused on coordinating and integrating government policy-making and service delivery across organizational boundaries (Mulgan, 2005). A whole-of-government approach needs a cooperative effort and cannot be imposed from the top down (Pollitt, 2003; Edelenbos and Teisman, 2011). Joined-up government is described as the opposite of departmentalism, tunnel vision and vertical silos, and denotes the aspiration to achieve horizontal and vertical coordination, leading to agencies working across portfolio boundaries to achieve a shared goal and an integrated government approach (Christensen and Lægreid, 2007). Whole-of-government activities span any or all levels of government and involve groups outside government (Pollitt, 2003). The emergence of joined-up government and whole-of-government shows similarities with trends in the United States that stress management of boundaries and networks and cross-sector collaboration (Bryson et al., 2014, 2015).

In the literature on governance networks, the idea of how to integrate a fragmented reality shifts from classic instruments like law, reorganization and force to more subtle and less static means, conceptualized as network management and interactive policy-making (Agranoff and McGuire, 2003; Edelenbos, 2005). Network management focuses on strategic attempts to manage interactions between actors and ongoing processes in networks.

In urban governance the notion of central coordination should be abandoned (Edelenbos and Teisman, 2011). The argument is that the interactions in complex systems are too numerous and diverse. Complex processes are dynamic due to the existing degree of self-organization. A more deliberate network management strategy is applied in these networks (Klijn and 
Edelenbos, 2007). Deadlocks and disputes cannot be solved by force or authority. Integration in networks requires going beyond boundaries of layers and departments. Within this holistic network approach, the capacity to connect to other domains, levels, scales, organizations and actors becomes important, addressing interrelationships and linkages among multiple, cross-cutting, and often conflicting resource uses (Edelenbos et al., 2011; Edelenbos and Teisman, 2013).

Urban governance is perceived to have an "evolutionary advantage", as networking enables innovation and learning in a constantly changing environment, which is characterized by situations of complex reciprocal interdependence among relatively autonomously operating stakeholders with private and shared interests, values and viewpoints (Jessop, 1998: 32-33). The capacity to get things done "no longer lies (if it ever did) with government power and authority in one place" (Kearns and Paddison, 2000: 847).

\section{Eclectic Approaches}

All paradigms have merits and weaknesses (Table 1.2). Public administration enables the top-down delivery of low-cost infrastructure and services but may lead to government failure and does not differentiate between local specificities. Urban management can tailor services to local needs, but may lead to market failure and cannot address wicked problems. Urban governance, finally, can address wicked problems, but may lead to network failure especially in cities with limited capacity to manage networks. Finding the best approach, which navigates between market, state and network failure, is space- and path-dependent.

In their constant search for solutions to problems, cities can explore a number of new approaches, such as smart city, resilient city, green city, competitive city and/or innovative city. Each addresses urban development from a different content angle. They recommend the what, while paradigms recommend the how. In practice, they may represent a fancy city brand, as all cities want to be smart, resilient and inclusive. We discuss how these concepts eclectically and implicitly integrate theory on governance, management and public administration.

\section{Resilient cities}

A resilient city can recover from an external shock and disturbance, which may be drought, flooding, an earthquake, a financial crisis, or a pandemic. Resilience involves three distinct stages: the ability to resist, to recover and to thrive (Elmqvist et al., 2019; Martin and Sunley, 2015). Resilience indicates the ability, time and cost needed for urban systems to bounce back to their previous equilibrium or to bounce forward (Martin and Sunley, 2015). The 
Table 1.2 An overview of urban paradigms

\begin{tabular}{lllll}
\hline $\begin{array}{l}\text { Urban paradigm and } \\
\text { main concepts }\end{array}$ & $\begin{array}{l}\text { Public } \\
\text { administration } \\
\text { paradigm }\end{array}$ & $\begin{array}{l}\text { Main mode of } \\
\text { governance }\end{array}$ & Main strength & Main weaknesses \\
\hline $\begin{array}{l}\text { Urban planning } \\
\text { - Centralization }\end{array}$ & $\begin{array}{l}\text { Traditional } \\
\text { Public }\end{array}$ & Public hierarchy & $\begin{array}{l}\text { Standardized } \\
\text { low-cost service }\end{array}$ & $\begin{array}{l}\text { Government failure } \\
\text { Crowding out }\end{array}$ \\
- Internal orientation & Administration & & and infrastructure & Power abuse \\
- Top-down planning & & delivery & Inefficiencies \\
Urban management & New Public & Market & Tailored low-cost & Market failure \\
- Decentralization & Management & & service and & Information \\
- Privatization/PPP & & infrastructure & asymmetries \\
- participation & & delivery & Opportunism \\
& & & Bounded rationality \\
Complex urban & New Public & Networks & Can address & Network failure \\
systems & Governance & & wicked problems & High transaction \\
- Networks & & & costs \\
- Multilevel & & & Limited control \\
& & & Vested interests \\
& & & Different scales \\
\hline
\end{tabular}

concept covers the resilience of urban social, environmental and economic systems (Ernstson et al., 2010; Martin and Sunley, 2015), urban communities (Fransen et al., 2021), urban organizations (Lebel et al., 2006) and/or the people living and working in a city (Peek, 2008).

The COVID-19 pandemic has placed urban resilience high on the political agenda. We witness that the phases of urban resilience roughly coincide with a paradigm shift. The immediate response to the COVID-19 pandemic has been one of centralized planning. Centralized and standardized rules (keep distance, wash hands, stay indoors, shops closed) have played a major role in the first (resist) and second (recover) phase of coping with the pandemic. Urban management enables a targeted and localized response, such as local policing, closing off public spaces and supporting community initiatives. At the same time, the multiple initiatives of communities and firms in providing much-needed medical equipment such as masks, offering solace to the lonely and shopping for the elderly, illustrate the need for urban governance and especially play a role in the second (recovery) and third phase (thriving). Learning and thriving from a crisis demands localized and adaptive governance (Olsson et al., 2004). It defines the city after the pandemic which learns to thrive through more resilient organizations, communities, economies and people. These phases and levels of resilience are interlinked and non-linear: the lessons learned, initiatives and solidarities at multiple layers during phases 1 and 2 
lay the basis for phase 3 . Phase 3 subsequently informs the ability to cope with the next crisis, be it a second wave of COVID-19 or some other crisis. This requires an eclectic mix of public administration, urban management and urban governance. This is easier said than done, as each phase has its own actors, objectives and speed.

\section{Creative and competitive cities}

Scholars widely discuss the role of actors and perspectives in urban economics. Hall and Soskice (2001) for instance identify two opposing paradigms, which they call varieties of capitalism: liberal market economies, which resemble New Public Management, and coordinated market economies, which resemble Network Governance. Markets steer development in a liberal market economy, while non-market forms of interaction are the primary drivers in coordinated market economies.

Porter (1996), as a proponent of liberal market economies, argues that firms locate industries and services close to markets, firms, research labs and universities. The role of urban managers is to create an enabling environment. At its core is the efficient urban management of inner-city revitalization, preferably in public-private partnerships (Porter, 1997). However, others argue in favour of network governance because urban competitiveness is not only dependent on local firms but also on creative people. Network governance can identify how to make cities attractive for the creative class (Florida, 2004) and how to operate in global value chains (Fransen and Helmsing, 2017). Katz and Wagner (2014) propose a specific role of government to develop geographically bounded innovation districts, which house leading-edge anchor institutions and clustered companies, business incubators and accelerators. They offer a breeding ground for start-ups. These innovation districts are physically compact, transit-accessible, technically wired and offer mixed use housing, office and retail. These urban economic approaches are discussed in forums such as economic development boards, comprising public, private and/or civil partners. This often links to a broader definition of competitiveness, arguing that not only productivity, but also sustainability and equality matter (Scott and Storper, 2015). A sole focus on creativity and competitiveness, alongside technological trends which take away jobs from the middle class, leads to inequality and a 'new urban crisis' (Florida, 2017; Fransen and Helmsing, 2016).

\section{Green/sustainable cities}

Green or sustainable cities reduce, recycle, and reuse waste, close their water cycle and address pollution. This demands a transition to integrated, circular and adaptive approaches in order to cope with increasing uncertainties generated, for example, by climate change (Van Dijk, 2012). In an ecological city, waste, energy and water management are integrated into a broader urban envi- 
ronment approach (Suzuki et al., 2010). Alongside environmental services, climate change adaption and mitigation, liveability and the quality of the urban environment are valued. As this is unknown territory, urban actors navigate the transition and discuss strategies in open governance processes. Urban governance thereby aims to promote the welfare of citizens in such a way that it does not have negative consequences for future generations.

Urban managers reassess risks, manage networks and co-create strategic, spatial and action plans to mitigate these risks. Urban management can therefore be defined as an integrated and comprehensive approach to deal with urban risks in cities (Van Dijk, 2009a). Climate change adds urgency and complexity. In forms of network governance, strategic and action plans create a shared vision and concrete activities for government, communities and firms. A more ecological approach to sustainable urbanization implies moving from traditional environmental technologies to more ecosan options (sanitary solutions with ecological characteristics) in the ecological city of the future (Van Dijk, 2009b).

\section{Smart cities}

While the concept 'smart city' has become powerful in influencing urban development worldwide, it lacks a uniform definition or practice. Instead, there are many different perspectives, narratives and practices leading to different urban development trajectories (Kummitha and Crutzen, 2017). The first definitions of a smart city focused on the role of information and communication technologies (ICTs), such as information and technology infrastructure, smart technologies, mobile technologies, virtual technologies and digital networks (Huovila et al., 2019: 145). In practice, this approach is closely interwoven with New Public Management, whereby city councils and ICT firms take the lead in introducing ICT into urban management. While the use of ICT has many advantages, scholars argue that it often leads to inequality, a digital divide and exclusion and it may reduce democratic processes (Datta, 2015; Kummitha and Crutzen, 2017; Nam and Pardo, 2011).

Later definitions place people and governance at the core of the smart city debate (Nam and Pardo, 2011: 286). This relates to the concept of soft smartness (Huovila et al., 2019). Knowledge, education, social learning and creativity constitute important criteria to enhance the performance of a smart city (Nam and Pardo, 2011; Castelnovo et al., 2016). Authors also emphasize the link between smart and sustainable (Höjer and Wangel, 2015). Others emphasize inclusive, democratic and polycentric approaches, whereby new solutions are co-created in living labs. This approach is used in Amsterdam for instance, but the practice also shows that many local experiments do not necessarily scale up to a smart city with smart citizens (Van Winden and van den Buuse, 2017). 


\section{WHAT IS NEXT?}

After decades of market-led development, governments and networks appear to be taking up a larger role once again. Governments have played a central role in infrastructure-led development in emerging economies. This has materialized in constructing new cities which are smart, often implemented in public-private partnerships. The role of government has also (temporarily) been enlarged in coping with the COVID-19 pandemic. At the same time, the climate change transition has resulted in a critical outlook on the ability of the private sector to organize sustainable development.

We expect (local) governments and networks to carve out a larger role for themselves in the foreseeable future in order to manage transitions and navigate crises. The era of market-led development may have come to an end. This trend may lead to new (combinations of) paradigms. We introduce the Governance Possibility Frontier in order to assess the space for local actors to operate within different local contexts. We subsequently discuss boundary spanning as a tool to make the Governance Possibility Frontier work.

\section{Governance Possibility Frontier}

Social urban life is coordinated by hierarchies, markets and networks; neither one surpasses the others. For example, neither the market nor hierarchy will lead to proper coordination, as both neglect the informal mechanisms that typify a network (Thompson, 1991). Coordination of urban life will always require certain blends of the three where one can dominate over the other. Urban societies operate in different political settings within which either a government, market or network mode of governance dominates. They represent structurally different solutions to urban problems. While most urban societies combine approaches, their extremes are seen in socialist dictatorships, market-driven societies and network societies. We propose a Governance Possibility Frontier (adapted from Djankov et al., 2003), which indicates the minimum level of planning, management and governance required to address wicked urban problems and to protect people from misuse and opportunism of public, civil and private parties. Its defining characteristic is that different political settings offer different competences and comparative advantages in planning, management and/or governance. We argue that to function at a minimum level, a benevolent dictator would require a competent government in combination with a minimum level of resilient, competent and self-organized communities, functioning markets and social networks. If well-functioning, it is relatively likely to excel in top-down urban planning and perform worse in addressing varied needs, local initiatives, constant market fluctuations and wicked 
problems. By the same token, a competent network society may excel in framing wicked problems, but face challenges in effective and efficient service delivery. Besides networks, it therefore requires a minimum competence in government hierarchies and markets. Finally, a market-driven society may excel in responsiveness to fluctuations, but it requires a minimum competence of government hierarchy and networks to overcome market failure.

\section{Boundary Spanning}

The interdependency of government, market and networks implies that boundaries are permeable and not set in stone (Stoker, 1995). Coordinating and integrating urban planning, management and governance requires crossing boundaries, because solving problems in one domain might imply new issues and problems in others. Urban professionals have to become boundary spanners, defined as "people who proactively scan the organizational environment, employ activities to cross organizational or institutional boundaries, generate and mediate the information flow and coordinate between their 'home' organization or organizational unit and its environment, and connect processes and actors across these boundaries" (Van Meerkerk and Edelenbos, 2018: 3). Four types of boundary spanners are distinguished: fixer, bridger, broker and innovator, each with their specific focus and core competences as displayed in Table 1.3.

Boundaries can be spanned through boundary objects. Boundary objects provide a shared language that allows for representing the domain-specific knowledge in a structure and format that are known on the other side of the knowledge boundary (Carlile, 2002). Examples are work manuals, intranet and forms, which usually try to cross boundaries between management and workforce. Urban professionals - scientists, policy makers and representatives of stakeholder organizations - can generate, integrate and apply boundary objects and thereby relate to, understand and interact between planners, managers and governors across sectors and organizations (Edelenbos and Teisman, 2011; Van Meerkerk and Edelenbos, 2018).

\section{CONCLUSION}

Since the 1980s, paradigms to understand and intervene in cities have shifted from hierarchy (Traditional Public Administration), to markets (Urban Management) and finally to networks (Urban Governance). This reflects a radical change in the way we manage cities. The radical change reflects a pendulum, whereby market, government or network failure swing the pendulum back and forth. Rapid urbanization and shocks such as climate change and the COVID-19 pandemic make the pendulum swing faster and faster. We 
Table 1.3 Four boundary spanning profiles

\begin{tabular}{|c|c|c|c|c|}
\hline & Fixer & Bridger & Broker & Innovator \\
\hline $\begin{array}{l}\text { Is a person } \\
\text { who ... }\end{array}$ & $\begin{array}{l}\text { is oriented at } \\
\text { solving problems } \\
\text { in cross-boundary } \\
\text { endeavours } \\
\text { and aligning } \\
\text { organizational } \\
\text { policies with external } \\
\text { processes. }\end{array}$ & $\begin{array}{l}\text { focuses on creating } \\
\text { connections } \\
\text { between people } \\
\text { from different } \\
\text { organizations } \\
\text { and promoting } \\
\text { cross-boundary } \\
\text { endeavours. }\end{array}$ & $\begin{array}{l}\text { is active in } \\
\text { facilitating and } \\
\text { mediating concrete } \\
\text { interactions and } \\
\text { dialogues among } \\
\text { actors with } \\
\text { different interests } \\
\text { and organizational } \\
\text { backgrounds. }\end{array}$ & $\begin{array}{l}\text { explores new } \\
\text { ideas, products } \\
\text { and processes } \\
\text { crossing public, } \\
\text { private and societal } \\
\text { boundaries, looking } \\
\text { for opportunities to } \\
\text { develop support and } \\
\text { mobilize resources } \\
\text { for proposed } \\
\text { initiatives. }\end{array}$ \\
\hline $\begin{array}{l}\text { Main } \\
\text { competences } \\
\text { and activities }\end{array}$ & $\begin{array}{l}\text { Represents external } \\
\text { views in the } \\
\text { organization and vice } \\
\text { versa; reading the } \\
\text { situation; pragmatic } \\
\text { and implementation } \\
\text { oriented; result } \\
\text { driven; information } \\
\text { scanning and } \\
\text { exchange activities; } \\
\text { relationship building }\end{array}$ & $\begin{array}{l}\text { Strong network; } \\
\text { trustworthy } \\
\text { person with } \\
\text { good reputation; } \\
\text { ambassador } \\
\text { activities for } \\
\text { cross-boundary } \\
\text { endeavours; } \\
\text { highly developed } \\
\text { interpretation, } \\
\text { communication and } \\
\text { translation skills }\end{array}$ & $\begin{array}{l}\text { Highly developed } \\
\text { facilitation and } \\
\text { negotiation } \\
\text { skills; finding } \\
\text { and expressing } \\
\text { common ground; } \\
\text { empathetic; good } \\
\text { listener; good } \\
\text { interpreter and } \\
\text { translator }\end{array}$ & $\begin{array}{l}\text { Highly developed } \\
\text { sense for seeing } \\
\text { and seizing } \\
\text { opportunities; } \\
\text { entrepreneurial } \\
\text { drive; motivating } \\
\text { and inspiring; } \\
\text { mobilizing capacity; } \\
\text { daring to take risks }\end{array}$ \\
\hline
\end{tabular}

Source: Adapted from Van Meerkerk and Edelenbos (2018: 111).

expect that urban resilience will be placed higher on the urban agenda due to the current pandemic and climate change. As markets have failed to provide urban resilience, we expect government hierarchy and/or governance to play a larger role in the near future.

Cities in emerging economies ultimately require an eclectic mix of the three perspectives. This is easier said than done, as each perspective has its own actors, political priorities, decision-making model and speed. It requires constant reflection, learning, creativity and organizational innovation across different actors and levels. Urban governance is perceived to have an 'evolutionary advantage', as networking enables innovation and learning in a constantly changing environment (Jessop, 1998). Authoritarian or market-driven development are thus likely to face greater difficulty in adjusting their pendulum.

New approaches emerge on an almost daily basis and propose that urban managers should make their city smart, resilient, creative, inclusive and/ 
or sustainable. They all address urban development from different content angles, but the concepts often remain blurry with major conflicts of opinion between scholars within each approach. Cities in emerging economies adopt one or more of these approaches and do so in hierarchical, market-driven or network mode depending on their own context and history. In our experience, the choice of how to develop cities (the paradigms) is as important as what to develop (the approaches). We use a Governance Frontier Model to compare the perspectives internationally, whereby the frontier may differ per approach.

This book aims to explore the different paradigms (how) for different approaches (what) applied by different cities in emerging economies (where). That is ambitious. The endless variety of how cities deal with wicked problems in complex environments constitutes a worldwide evolutionary experiment. A lot is at stake, as urban managers in emerging economies often lack political, financial and human resources to deal with rapid urbanization, climate change and crises. This book offers inspiration and an update on recent theories and practices.

\section{REFERENCES}

Agranoff, R. and McGuire, M. (2003). Collaborative Public Management: New Strategies for Local Governments. Washington, DC: Georgetown University Press.

Bartels, K. P. R. (2016). Doing what's necessary: How encounters in practice shape and improve interactive governance work. In Critical Reflections on Interactive Governance, ed. J. Edelenbos and I. Van Meerkerk. Cheltenham, UK and Northampton, MA, USA: Edward Elgar Publishing, 352-375.

Bertaud, A. (2018). Order Without Design: How Markets Shape Cities. Cambridge, MA: MIT Press.

Bettencourt, L. M. (2013). The origins of scaling in cities. Science, 340(6139), 1438-1441.

Bryson, J. M., Crosby, B. C. and Bloomberg, L. (2014). Public value governance: Moving beyond traditional public administration and the new public management. Public Administration Review, 74(4), 445-456.

Bryson, J. M., Crosby, B. C. and Bloomberg, L. (eds.) (2015). Public Value and Public Administration. Washington, DC: Georgetown University Press.

Carlile, P. R. (2002). A pragmatic view of knowledge and boundaries: Boundary objects in new product development. Organization Science, 13(4), 442-455.

Castelnovo, W., Savoldelli, A. and Misuraca, G. (2016). Smart cities governance: The need for a holistic approach to assessing urban participatory policy making. Social Science Computer Review, 34(6), 724-739.

Cheema, G. S. (ed.) (1993). Urban Management: Policies and Innovations in Developing Countries. New York: Praeger.

Christensen, T. and Lægreid, P. (2007). The whole of government approach to public sector reforms. Public Administration Review, 67(6), 1059-1066.

Datta, A. (2015). New urban utopias of postcolonial India: 'Entrepreneurial urbanization' in Dholera Smart City, Gujarat. Dialogues in Human Geography, 5(1), 3-22. 
De Soto, H. (1989). The Other Path: The Invisible Revolution in the Third World. New York: Harper \& Row.

Denhardt, R. B. and Denhardt, J. V. (2000). The new public service: Serving rather than steering. Public Administration Review, 60(6), 549-559.

Devas, N. and Radkodi, C. (eds.) (1993). Managing Fast Growing Cities: New Approaches to Urban Planning and Management in the Developing World. Harlow: Longman.

Djankov, S., Glaeser, E., La Porta, R., Lopez-de-Silanes, F. and Shleifer, A. (2003). The new comparative economics. Journal of Comparative Economics, 31(4), 595-619.

Du Gay, P. (2008). Without affection or enthusiasm: Problems of involvement and attachment in responsive public management. Organization, 15(3), 335-353.

Duranton, G. and Puga, D. (2004). Micro-foundations of urban agglomeration economies. In Handbook of Regional and Urban Economics, vol. 4, ed. J. V. Henderson and J.-F. Thisse. Amsterdam: North-Holland, 2063-2117.

Edelenbos, J. (2005). Institutional implications of interactive governance: Insights from Dutch practice. Governance, 18(1), 111-134.

Edelenbos, J. and Teisman, G. R. (2011). Numéro spécial sur la gouvernance de l'eau. Revue Internationale des Sciences Administratives, 77(1), 5-30.

Edelenbos, J. and Teisman, G. (2013). Water governance capacity: The art of dealing with a multiplicity of levels, sectors and domains. International Journal of Water Governance, 1(1-2), 89-108.

Edelenbos, J., Van Buuren, A. and van Schie, N. (2011). Co-producing knowledge: Joint knowledge production between experts, bureaucrats and stakeholders in Dutch water management projects. Environmental Science \& Policy, 14(6), 675-684.

Elmqvist, T., Andersson, E., Frantzeskaki, N., McPhearson, T., Olsson, P., Gaffney, O. and Folke, C. (2019). Sustainability and resilience for transformation in the urban century. Nature Sustainability, 2(4): 267-273.

Ernstson, H., van der Leeuw, S. E., Redman, C. L., Meffert, D. J., Davis, G., Alfsen, C. and Elmqvist, T. (2010). Urban transitions: On urban resilience and human-dominated ecosystems. Ambio, 39(8): 531-545.

Florida, R. (2004). The Rise of the Creative Class. New York: HarperCollins.

Florida, R. (2017). The New Urban Crisis: How Our Cities Are Increasing Inequality, Deepening Segregation, and Failing the Middle Class - and What We Can Do About It. New York: Basic Books.

Fransen, J. and Helmsing, A. H. J. (2016). Breaching the barriers: The segmented business and innovation system of handicraft exports in Cape Town. Development Southern Africa, 33(4), 486-501.

Fransen, J. and Helmsing, A. H. J. (2017). Absorptive capacity as a mediator: Innovation of handicraft exporters in Yogyakarta, Indonesia. Tijdschrift voor economische en sociale geografie, 108(6), 737-752.

Fransen, J., Peralta, D. O., Vanelli, F., Edelenbos, J. and Olvera, B. C. (2021). The emergence of urban community resilience initiatives during the COVID-19 pandemic: An international exploratory study. The European Journal of Development Research, Special Issue (January), 1-23.

Hall, P. A. and Soskice, D. (eds.) (2001). Varieties of Capitalism: The Institutional Foundations of Comparative Advantage. Oxford: Oxford University Press.

Haque, M. S. (2007). Revisiting the New Public Management. Public Administration Review, 67(1): 179-182.

Head, B. W. and Alford, J. (2015). Wicked problems: Implications for public policy and management. Administration \& Society, 47(6), 711-739. 
Healey, P. (1995). Managing Cities: The New Urban Context. New York: John Wiley $\&$ Sons.

Hemerijck, A. (2013). Changing Welfare States. Oxford: Oxford University Press.

Höjer, M. and Wangel, J. (2015). Smart sustainable cities: Definition and challenges. In ICT Innovations for Sustainability, ed. L. Hilty and B. Aebischer. Cham: Springer, 333-349.

Hood, C. (1991). A public management for all seasons. Public Administration, 69(1): $3-19$.

Huovila, A., Airaksinen, M. and Bosch, P. (2019). Comparative analysis of standardized indicators for smart sustainable cities: What indicators and standards to use and when? Cities 89, 141-153.

Jaret, J. (1983). Recent neo-Marxist urban analysis. Annual Review of Sociology, 9, 499-525.

Jessop, B. (1998). The rise of governance and the risks of failure: The case of economic development. International Social Science Journal, 50(155), 29-45.

Katz, B. and Wagner, J. (2014). The Rise of Innovation Districts: A New Geography of Innovation in America. Washington, DC: Brookings Institution.

Kearns, A. and Paddison, R. (2000). New challenges for urban governance. Urban Studies, 37(5-6), 845-850.

Keynes, J. M. (1936). Allgemeine Theorie der Beschäftigung, des Zinses und des Geldes (Vol. 6). Berlin: Duncker \& Humblot.

Kickert, W. J., Klijn, E. H. and Koppenjan, J. F. (eds.) (1997). Managing Complex Networks: Strategies for the Public Sector. London: Sage.

Klijn, E. H. and Edelenbos, J. (2007) Meta-governance as network management. In Theories of Democratic Network Governance, ed. E. Sørensen and J. Torfing. Basingstoke: Palgrave Macmillan, 199-214.

Kooiman, J. (2003). Governing as Governance. London: Sage.

Koppenjan, J. F. M. and Klijn, E. H. (2004). Managing Uncertainties in Networks: A Network Approach to Problem Solving and Decision Making. London: Routledge.

Kuhn, T. S. (2012). The Structure of Scientific Revolutions, 50th anniversary edition. Chicago: University of Chicago Press.

Kummitha, R. K. R. and Crutzen, N. (2017). How do we understand smart cities? An evolutionary perspective. Cities, 67, 43-52.

Lebel, L., Anderies, J. M., Campbell, B., Folke, C., Hatfield-Dodds, S., Hughes, T. P. and Wilson, J. (2006). Governance and the capacity to manage resilience in regional social-ecological systems. Ecology and Society, 11(1). http://www .ecologyandsociety.org/vol11/iss1/art19/.

Martin, R. and Sunley, P. (2015). On the notion of regional economic resilience: Conceptualization and explanation. Journal of Economic Geography, 15(1), 1-42.

Mulgan, G. (2005). Joined-up government: Past, present and future. In Joined-Up Government, ed. V. Bogdanor. New York: Oxford University Press, 175-187.

Nam, T. and Pardo, T. A. (2011). Conceptualizing smart city with dimensions of technology, people, and institutions. In Proceedings of the 12th Annual International Digital Government Research Conference: Digital Government Innovation in Challenging Times, ed. J. Bartot et al. New York: ACM Press, 282-291.

Nederhand, J., Van Der Steen, M. and Van Twist, M. (2019). Boundary-spanning strategies for aligning institutional logics: A typology. Local Government Studies, 45(2), 219-240. 
Neffke, F., Hartog, M., Boschma, R. and Henning, M. (2018). Agents of structural change: The role of firms and entrepreneurs in regional diversification. Economic Geography, 94(1), 23-48.

Olsson, P., Folke, C. and Berkes, F. (2004). Adaptive co-management for building resilience in social-ecological systems. Environmental Management, 34(1), 75-90.

Osborne, S. P. (2006). The New Public Governance. Public Management Review, 8(3), 377-387.

Peek, L. (2008). Children and disasters: Understanding vulnerability, developing capacities, and promoting resilience - an introduction. Children, Youth and Environments, 18(1), 1-29.

Pollitt, C. (2003). Joined-up government: Survey. Political Studies Review, 1, 34-49.

Pollitt, C., van Thiel, S., and Homburg, V. (eds.) (2007). New Public Management in Europe: Adaptations and Alternatives. Basingstoke: Palgrave Macmillan.

Porter, M. E. (1996). Competitive advantage, agglomeration economies, and regional policy. International Regional Science Review, 19(1-2), 85-90.

Porter, M. E. (1997). New strategies for inner-city economic development. Economic Development Quarterly, 11(1), 11-27.

Rhodes, R. (1996). The new governance: Governing without governance. Political Studies, 44, 652-667.

Rittel, H. W. J. and Webber, M. M. (1973). Dilemmas in a general theory of planning. Policy Sciences, 4(2), 155-169.

Roberts, L. (2011). 9 Billion? Science, 333(6042), 540-543.

Rostov, W. (1960). The Stages of Economic Growth. Cambridge: Cambridge University Press.

Sahn, D. E., Dorosh, P. A. and Younger, S. D. (1999). Structural Adjustment Reconsidered: Economic Policy and Poverty in Africa. Cambridge: Cambridge University Press.

Scott, A. J. and Storper, M. (2015). The nature of cities: The scope and limits of urban theory. International Journal of Urban and Regional Research, 39(1), 1-15.

Stiglitz, J. E. (1991). The Invisible Hand and Modern Welfare Economics (NBER Working Paper 3641). Cambridge, MA: National Bureau of Economic Research.

Stiglitz, J. E. (1998). The private uses of public interests: Incentives and institutions. Journal of Economic Perspectives, 12(2), 3-22.

Stoker, G. (1995). Regime theory and urban politics. In Theories of Urban Politics, ed. D. Judge, G. Stoker and H. Wolman. London: Sage, 54-71.

Stoker, G. (2006). Public value management: A new narrative for networked governance? The American Review of Public Administration, 36(1), 41-57.

Suzuki, H., Dastur, A., Moffatt, S., Yabuki, N. and Maruyama, H. (2010). Eco ${ }^{2}$ Cities: Ecological Cities as Economic Cities. Washington, DC: World Bank.

Thompson, G. (ed.) (1991). Markets, Hierarchies and Networks: The Coordination of Social Life. London: Sage.

Tonkinwise, C. (2015). Design for transitions: From and to what? Design Philosophy Papers, 13(1), 85-92.

Torfing, J., Peters, B. G., Pierre, J., and Sørensen, E. (2012). Interactive Governance: Advancing the Paradigm. Oxford: Oxford University Press.

Van Dijk, M. P. (2006). Managing Cities in Developing Countries. Cheltenham, UK and Northampton, MA, USA: Edward Elgar Publishing.

Van Dijk, M. P. (2009a). Urban water governance as part of a strategy for risk mitigation: What is different in third world cities? In Building Safer Communities, ed. F. Urbano. Amsterdam: IOS Press, 182-200. 
Van Dijk, M. P. (2009b). Ecological cities, illustrated by Chinese examples. In Climate Change and Sustainable Development: New Challenges for Poverty Reduction, ed. M. A. M. Salih. Cheltenham, UK and Northampton, MA, USA: Edward Elgar Publishing, 214-233.

Van Dijk, M. P. (ed.) (2012). Water Governance. Special issue of the International Journal of Water.

Van Meerkerk, I. and Edelenbos, J. (2018). Boundary Spanners in Public Management and Governance: An Interdisciplinary Assessment. Cheltenham, UK and Northampton, MA, USA: Edward Elgar Publishing.

Van Winden, W. and van den Buuse, D. (2017). Smart city pilot projects: Exploring the dimensions and conditions of scaling up. Journal of Urban Technology, 24(4), $51-72$.

Weber, M. (1978). Economy and Society: An Outline of Interpretive Sociology. Berkeley: University of California Press.

WHO (2018). Ambient air pollution. https://www.who.int/airpollution/data/cities/en/.

Wilson, J. Q. (1989). Bureaucracy: What Government Agencies Do and Why They Do It. New York: Basic Books.

World Bank (2000). Attacking Poverty. World Bank Development Report. New York: Oxford University Press. 